\title{
Studies on Morphological Variability of the Fungal Pathogen, Lasiodiplodia theobromae causing Dieback in Mango
}

\author{
M. Dheivam ${ }^{1}$, K. Manonmani ${ }^{1 *}$, K. Kalpana ${ }^{1}$, C. Senthilraja $^{2}$, \\ M. Theradimani ${ }^{1}$ and J. Rajangam ${ }^{3}$ \\ ${ }^{1}$ Department of Plant Pathology, Agricultural College and Research Institute, \\ Tamil Nadu Agricultural University, Madurai, India \\ ${ }^{2}$ Department of Plant Protection, ${ }^{3}$ Department of Fruit Science Horticultural College and \\ Research Institute, Tamil Nadu Agricultural University, Periyakulam, India \\ *Corresponding author
}

\section{A B S T R A C T}

\begin{tabular}{|l|}
\hline Ke y w o r d s \\
Mango dieback, \\
$\begin{array}{l}\text { Lasiodiplodia } \\
\text { theobromae, } \\
\text { Morphological } \\
\text { variability }\end{array}$ \\
\hline Article Info \\
\hline $\begin{array}{l}\text { Accepted: } \\
16 \text { November } 2020 \\
\text { Available Online: } \\
10 \text { December } 2020\end{array}$ \\
\hline
\end{tabular}

Mango (Mangifera indica Linn.) is the "king of fruits" originated from South East Asia. Mango is affected by many biotic stresses; among them dieback is one of the serious diseases incited by the fungus Lasiodiplodia theobromae. Roving survey conducted in Tamil Nadu revealed the maximum disease incidence of $55.84 \%$ in Mulaiyur village (ILtDM10) of Dindigul district and minimum disease incidence of $8.95 \%$ in Ettipatti village (ILtDM17) of Krishnagiri district, Tamil Nadu. Major symptoms observed were defoliation of infected leaves, tip dieback, bark, twigs drying, shrivelling of twigs, vascular discolouration, and finally death of plants. Thirty numbers of pathogen isolates were collected from the diseased plant parts collected during the survey and pure cultures of them were established. The morphological characteristics of the pure cultures were studied and the pathogen growth was initially white, later on grey to dark greyish black with black to dark black pigmentation. Conidia were initially hyaline, unicellular, sub ovoid to ellipsoid and mature conidia were dark brown to black, bi-celled, ellipsoid, thick walled with longitudinal striations. The size of the conidia varied between $18.4-26.8 \times 10.6-$ $14.2 \mu \mathrm{m}$.

\section{Introduction}

Mango (Mangifera indica Linn.) "King of fruits" has its origin from South East Asia. It belongs to the family Anacardiaceae. It is a major fruit tree grown in more than 90 countries in tropical and subtropical regions of the world (Al-Jabri et al., 2017). India rank first among the mango producing countries accounting for $42 \%$ of the world production, followed by China 11\% (FAO, 2015). In India, area and production is about 2.313 million ha and 22.353 million tonnes respectively (NHB, 2018 - 2019). The major mango growing states in India are Uttar Pradesh, Tamil Nadu, Andhra Pradesh, Bihar, Karnataka and Gujarat. 
Mango is affected by various biotic and abiotic stresses that reduce the quantity and quality of the produce. The important diseases viz., anthracnose, dieback, powdery mildew, and mango malformation are the major constraints in mango production in India. Among these, the most destructive disease is dieback incited by the fungus Lasiodiplodia theobromae. It causes yield loss in field (pre-harvest disease- dieback) as well as in storage condition (post-harvest diseases-Stem end rot/ fruit rot). This disease has been reported in several countries viz., India, China, Pakistan, Brazil, USA, UAE, Korea, Oman (Sharma et al., 1994; Ploetz et al., 1996; Al-Adawi et al., 2003; Khanzada et al., 2004; de Oliveira Costa et al., 2010; Hong et al., 2012; Saeed et al., 2017).

This pathogen is a hemibiotrophic plant pathogen (Tudzynski and Sharon, 2003) and causes severe damage to its hosts. It causes variety of symptoms and named based on the affected plant parts and symptoms such as dieback, gummosis, stem end rot, blights, stem necrosis, root rot, leaf spot etc., (Punithalingam, 1980; Úrbez-Torres et al., 2008). The symptoms are primarily observed at twigs, subsequently spreading to its branches followed by infection in all branches, ultimately resulting in death of the plant. The present research focuses on survey, pathogen isolation and studying the morphological variability in the pathogen causing mango die-back.

\section{Materials and Methods}

\section{Survey and collection of diseased samples}

Roving survey was taken up in various mango growing hotspots in Tamil Nadu during summer, 2019. The percent dieback incidence was assessed in 30 villages representing 10 districts (Table 1). Data like location (latitude, longitude), variety, age of trees and disease incidence were collected. Disease incidence (\%) was calculated by the following formula (Teng and James, 2002).

$\mathrm{I}(\%)=(\mathrm{ni} / \mathrm{N}) \times 100$

where $\mathrm{I}=$ Disease incidence $(\%)$, ni $=$ total number of diseased trees, $\mathrm{N}=$ total number of trees observed.

Variation in the symptoms in mango plants caused by the disease was also recorded.

\section{Isolation and identification of the pathogen}

During the survey, infected plant samples (twigs) were collected and used for isolation of pathogen. The collected twigs were approximately cut into $0.2-0.5 \mathrm{~cm}$ in size (Saeed et al., 2017) and surface sterilised using $1 \%$ sodium hypochlorite for $2 \mathrm{~min}$ followed by gentle rinse in sterilized distilled water three times and tissues dried using sterilized tissue paper (Al-Jabri et al., 2017). The surface sterilized tissues were placed on Petri dish containing sterilized Potato Dextrose Agar (PDA) medium amended with the bacterial antibiotic, streptomycin sulphate and incubated at room temperature for 3 days. The pure culture of the pathogen was obtained by single hyphal tip method (Dhingra and Sinclair, 1985) and stored in PDA slants at $4^{0} \mathrm{C}$ for further studies.

\section{Morphological variability}

Morphological variability of pathogenic isolates was studied by growing the purified isolates on PDA medium. Cultural characters viz., colour (observe and reverse), topography, margin, zonation and days taken to cover the Petri dish were recorded (Sathya et al., 2017). Spore characters were also studied based on the production of pycnidium and spores, colour, shape and size (length and breadth) of the spores using compound microscope 
(Phillips et al., 2013). The intensity of sporulation was measured by using the following grades: - no, + poor, ++ medium, and $+++\operatorname{good}($ Sathya et al., 2017).

\section{Results and Discussion}

\section{Survey and collection of diseased samples}

Roving survey on disease incidence in 30 different locations revealed the extent of dieback disease infection in major mango areas of Tamil Nadu (Table 1). Among thirty villages, maximum disease incidence was recorded in Mulaiyur village (ILtDM10) in
Dindigul district (55.84\%) followed by Andiyur village (ILtDM19) in Krishnagiri District with $53.84 \%$ disease incidence. The minimum disease incidence was recorded in Ettipatti village (ILtDM17) of Krishnagiri District (8.95\%) (Plate 1; Fig. 1). Similarly, dieback disease incidence was reported to be $30-40 \%$ in Uttar Pradesh (Prakash and Srivastava, 1987), $0-40 \%$ in Andhra Pradesh (Madduleti, 1989), $89.4 \%$ in Al Batinah region of Oman (Al Adawi et al., 2006), 3.71 - 29.71\% in Peru (RodríguezGálvez et al., 2017), 6 - 42 \% in Oman (AlJabri et al., 2017).

Table.1 Survey for incidence of mango dieback disease in Tamil Nadu

\begin{tabular}{|c|c|c|c|c|c|c|c|c|}
\hline \multirow[t]{2}{*}{ S. No. } & \multicolumn{2}{|c|}{ Location } & \multirow[t]{2}{*}{ Village } & \multirow[t]{2}{*}{ District } & \multirow{2}{*}{$\begin{array}{c}\text { Isolate } \\
\text { Code }\end{array}$} & \multirow[t]{2}{*}{ Variety } & \multirow{2}{*}{$\begin{array}{c}\text { Age of } \\
\text { trees } \\
\text { (Years) }\end{array}$} & \multirow{2}{*}{$\begin{array}{c}\text { Disease } \\
\text { Incidence } \\
(\%)\end{array}$} \\
\hline & Latitude & Longitude & & & & & & \\
\hline 1 & 9.975802 & 78.206805 & AC\&RI (MDU) & \multirow[t]{4}{*}{ Madurai } & ILtDM1 & Bangalora & 10 & 12.90 \\
\hline 2 & 9.994748 & 77.974122 & Melakkal & & ILtDM2 & Neelum & 12 & 29.70 \\
\hline 3 & 10.103769 & 78.002029 & Kutladampatti & & ILtDM3 & Alphonso & 15 & 27.86 \\
\hline 4 & 10.103239 & 78.106822 & Palamedu & & ILtDM4 & Bangalora & 15 & 43.75 \\
\hline 5 & 10.124304 & 77.592151 & HC\&RI (PKM) & \multirow[t]{4}{*}{ Theni } & ILtDM5 & Bangalora & 16 & 18.47 \\
\hline 6 & 10.049305 & 77.586057 & Melmangalam & & ILtDM6 & Bangalora & 29 & 9.61 \\
\hline 7 & 10.179918 & 77.538597 & Kumbakarai & & ILtDM7 & Neelum & 18 & 41.80 \\
\hline 8 & 10.138443 & 77.519532 & Vadagarai & & ILtDM8 & Vadumangai & 21 & 13.15 \\
\hline 9 & 10.256757 & 78.126674 & Gopalpatti & \multirow[t]{4}{*}{ Dindigul } & ILtDM9 & Bangalora & 4 & 41.93 \\
\hline 10 & 10.220502 & 78.161245 & Mulaiyur & & ILtDM10 & Bangalora & 13 & 55.84 \\
\hline 11 & 10.232345 & 78.219566 & Velanpatti & & ILtDM11 & Banganapalli & 14 & 28.35 \\
\hline 12 & 10.186534 & 77.799800 & Nuthulapuram & & ILtDM12 & Alphonso & 6 & 14.10 \\
\hline 13 & 12.167489 & 78.557565 & Chandrapuram & \multirow[t]{4}{*}{ Dharmapuri } & ILtDM13 & Bangalora & 16 & 26.47 \\
\hline 14 & 12.070105 & 78.476869 & Mobripatti & & ILtDM14 & Bangalora & 10 & 46.51 \\
\hline 15 & 12.130029 & 78.414420 & Mottaiyanpatti & & ILtDM15 & Neelum & 14 & 46.03 \\
\hline 16 & 12.208179 & 78.060184 & Madhehalli & & ILtDM16 & Malgoa & 9 & 32.69 \\
\hline 17 & 12.318716 & 78.477068 & Ettipatti & \multirow[t]{4}{*}{ Krishnagiri } & ILtDM17 & Alphonso & 24 & 8.95 \\
\hline 18 & 12.354418 & 78.532969 & Vaduganur & & ILtDM18 & Banganapalli & 16 & 16.75 \\
\hline 19 & 12.351093 & 78.582652 & Andiyur & & ILtDM19 & Bangalora & 17 & 53.84 \\
\hline 20 & 12.201931 & 78.601207 & Nadupatti & & ILtDM20 & Bangalora & 23 & 21.80 \\
\hline 21 & 11.757643 & 78.041693 & Palbakki & \multirow[t]{4}{*}{ Salem } & ILtDM21 & Salemgundu & 24 & 30.50 \\
\hline 22 & 11.797774 & 78.025106 & Semmadapatti & & ILtDM22 & Bangalora & 27 & 14.50 \\
\hline 23 & 11.785663 & 77.871943 & Mangamethai & & ILtDM23 & Neelum & 21 & 25.60 \\
\hline 24 & 11.784840 & 77.872081 & Veerakkal & & ILtDM24 & Bangalora & 19 & 26.50 \\
\hline 25 & 12.781436 & 79.431387 & Sennaleri & Vellore & ILtDM25 & Bangalora & 25 & 22.20 \\
\hline 26 & 12.388515 & 78.591824 & Chinnarampatti & \multirow[t]{2}{*}{ Tiruppattur } & ILtDM26 & Alphonso & 20 & 33.52 \\
\hline 27 & 12.408924 & 78.590542 & Odayamuthur & & ILtDM27 & Neelum & 18 & 36.15 \\
\hline 28 & 10.359949 & 78.387436 & Lekkanayakkanpatti & \multirow[t]{2}{*}{ Trichy } & ILtDM28 & Neelum & 25 & 29.00 \\
\hline 29 & 10.290105 & 78.394796 & Nagamangalam & & ILtDM29 & Bangalora & 23 & 34.00 \\
\hline 30 & 9.162863 & 77.405140 & Puliyangudi & Tenkasi & ILtDM30 & Neelum & 12 & 31.03 \\
\hline
\end{tabular}


Table.2 Mycelial characters of isolates of $L$. theobromae

\begin{tabular}{|c|c|c|c|c|c|c|c|}
\hline \multirow{2}{*}{$\begin{array}{l}\text { S. } \\
\text { No. }\end{array}$} & \multirow{2}{*}{$\begin{array}{l}\text { Isolate } \\
\text { Code }\end{array}$} & \multicolumn{2}{|c|}{ Colour } & \multirow[t]{2}{*}{ Topography } & \multirow[t]{2}{*}{ Margin } & \multirow[t]{2}{*}{ Zonation } & \multirow{2}{*}{$\begin{array}{c}\text { Days to cover } \\
\text { Petri Dish } \\
(9 \mathrm{~cm}) *\end{array}$} \\
\hline & & Observe & Reverse & & & & \\
\hline 1 & ILtDM1 & $\begin{array}{c}\text { Greyish } \\
\text { white }\end{array}$ & Black & Aerial & Irregular & No & 3 \\
\hline 2 & ILtDM2 & Grey & Black & Aerial & Irregular & No & 3 \\
\hline 3 & ILtDM3 & White & Dark green to black & Fluffy & Smooth & No & 5 \\
\hline 4 & ILtDM4 & White & Dark green to black & Aerial & Irregular & No & 2 \\
\hline 5 & ILtDM5 & $\begin{array}{c}\text { Blackish } \\
\text { grey }\end{array}$ & Dark black & Aerial & Irregular & No & 3 \\
\hline 6 & ILtDM6 & $\begin{array}{c}\text { Greyish } \\
\text { black }\end{array}$ & Dark black & Aerial & Irregular & No & 3 \\
\hline 7 & ILtDM7 & $\begin{array}{l}\text { Greyish } \\
\text { white }\end{array}$ & Black & Aerial & Irregular & No & 3 \\
\hline 8 & ILtDM8 & Grey & Black & Aerial & Irregular & No & 3 \\
\hline 9 & ILtDM9 & $\begin{array}{l}\text { Greyish } \\
\text { black }\end{array}$ & Dark black & Aerial & Irregular & No & 2 \\
\hline 10 & ILtDM10 & Grey & Black & Aerial & Irregular & No & 3 \\
\hline 11 & ILtDM11 & White & Dark green to black & Aerial & Irregular & No & 2 \\
\hline 12 & ILtDM12 & $\begin{array}{l}\text { Greyish } \\
\text { white }\end{array}$ & Black & Aerial & Irregular & No & 2 \\
\hline 13 & ILtDM13 & $\begin{array}{l}\text { Greyish } \\
\text { white }\end{array}$ & Black & Aerial & Irregular & No & 3 \\
\hline 14 & ILtDM14 & White & Dark green to black & Aerial & Irregular & No & 4 \\
\hline 15 & ILtDM15 & Dark grey & Black & Aerial & Irregular & No & 3 \\
\hline 16 & ILtDM16 & Grey & Black & Aerial & Irregular & No & 2 \\
\hline 17 & ILtDM17 & $\begin{array}{l}\text { Blackish } \\
\text { grey }\end{array}$ & Dark black & Flat & Smooth & No & 3 \\
\hline 18 & ILtDM18 & Dark grey & Black & Aerial & Irregular & No & 3 \\
\hline 19 & ILtDM19 & $\begin{array}{l}\text { Greyish } \\
\text { white }\end{array}$ & Black & Aerial & Irregular & No & 3 \\
\hline 20 & ILtDM20 & Dark grey & Black & Fluffy & Smooth & No & 3 \\
\hline 21 & ILtDM21 & White & Dark green to black & Aerial & Irregular & No & 3 \\
\hline 22 & ILtDM22 & Dark grey & Black & Aerial & Irregular & No & 3 \\
\hline 23 & ILtDM23 & $\begin{array}{c}\text { Greyish } \\
\text { black }\end{array}$ & Dark black & Aerial & Irregular & No & 2 \\
\hline 24 & ILtDM24 & $\begin{array}{l}\text { Greyish } \\
\text { white }\end{array}$ & Black & Aerial & Irregular & No & 3 \\
\hline 25 & ILtDM25 & White & Dark green to black & Aerial & Irregular & No & 3 \\
\hline 26 & ILtDM26 & $\begin{array}{c}\text { Greyish } \\
\text { black }\end{array}$ & Dark black & Aerial & Irregular & No & 2 \\
\hline 27 & ILtDM27 & $\begin{array}{l}\text { Greyish } \\
\text { white }\end{array}$ & Black & Aerial & Irregular & No & 3 \\
\hline 28 & ILtDM28 & $\begin{array}{l}\text { Greyish } \\
\text { white }\end{array}$ & Black & Aerial & Irregular & No & 2 \\
\hline 29 & ILtDM29 & $\begin{array}{c}\text { Greyish } \\
\text { black }\end{array}$ & Black & Aerial & Irregular & $\begin{array}{c}\text { Concentric } \\
\text { zonation }\end{array}$ & 3 \\
\hline 30 & ILtDM30 & $\begin{array}{c}\text { Blackish } \\
\text { grey }\end{array}$ & Dark black & Aerial & Irregular & No & 2 \\
\hline
\end{tabular}

*Mean values of three replications 
Table.3 Spore characters of isolates of $L$. theobromae

\begin{tabular}{|c|c|c|c|c|c|c|}
\hline \multirow{2}{*}{$\begin{array}{l}\text { S. } \\
\text { No. }\end{array}$} & \multirow{2}{*}{$\begin{array}{l}\text { Isolate } \\
\text { Code }\end{array}$} & \multirow{2}{*}{$\begin{array}{l}\text { Pycnidia } \\
\text { production* }\end{array}$} & \multirow{2}{*}{$\begin{array}{l}\text { Shape of the } \\
\text { conidia }\end{array}$} & \multirow{2}{*}{$\begin{array}{c}\text { Conidia } \\
\text { production* }\end{array}$} & \multicolumn{2}{|c|}{ Size of conidia $(\mu \mathrm{m}) * *$} \\
\hline & & & & & Length & Breadth \\
\hline 1 & ILtDM 1 & ++ & Ellipsoid & ++ & 22.0 & 13.6 \\
\hline 2 & ILtDM 2 & ++ & Ellipsoid & + & 23.8 & 13.6 \\
\hline 3 & ILtDM 3 & ++ & Ellipsoid & + & 23.2 & 13.6 \\
\hline 4 & ILtDM 4 & + & Ellipsoid & + & 20.0 & 11.0 \\
\hline 5 & ILtDM 5 & ++ & Ellipsoid & +++ & 26.8 & 13.0 \\
\hline 6 & ILtDM 6 & +++ & Ellipsoid & +++ & 18.4 & 10.6 \\
\hline 7 & ILtDM 7 & ++ & Ellipsoid & ++ & 23.2 & 13.2 \\
\hline 8 & ILtDM 8 & + & Ellipsoid & + & 22.6 & 11.4 \\
\hline 9 & ILtDM 9 & +++ & Ellipsoid & +++ & 23.8 & 12.0 \\
\hline 10 & ILtDM 10 & ++ & Ellipsoid & +++ & 24.0 & 12.6 \\
\hline 11 & ILtDM 11 & + & Ellipsoid & + & 24.0 & 12.0 \\
\hline 12 & ILtDM 12 & ++ & Ellipsoid & ++ & 22.6 & 12.0 \\
\hline 13 & ILtDM 13 & +++ & Ellipsoid & +++ & 23.8 & 13.6 \\
\hline 14 & ILtDM 14 & + & Ellipsoid & + & 20.2 & 12.8 \\
\hline 15 & ILtDM 15 & + & Ellipsoid & + & 21.6 & 13.4 \\
\hline 16 & ILtDM 16 & +++ & Ellipsoid & +++ & 24.0 & 14.2 \\
\hline 17 & ILtDM 17 & + & Ellipsoid & + & 25.0 & 11.8 \\
\hline 18 & ILtDM 18 & + & Ellipsoid & + & 24.4 & 13.4 \\
\hline 19 & ILtDM 19 & ++ & Ellipsoid & ++ & 23.6 & 14.0 \\
\hline 20 & ILtDM 20 & + & Ellipsoid & + & 20.4 & 11.0 \\
\hline 21 & ILtDM 21 & ++ & Ellipsoid & + & 22.6 & 12.8 \\
\hline 22 & ILtDM 22 & + & Ellipsoid & + & 21.4 & 13.0 \\
\hline 23 & ILtDM 23 & + & Ellipsoid & + & 24.8 & 12.8 \\
\hline 24 & ILtDM 24 & + & Ellipsoid & + & 23.6 & 13.6 \\
\hline 25 & ILtDM 25 & + & Ellipsoid & + & 20.2 & 11.6 \\
\hline 26 & ILtDM 26 & + & Ellipsoid & + & 23.8 & 13.8 \\
\hline 27 & ILtDM 27 & ++ & Ellipsoid & + & 21.6 & 11.2 \\
\hline 28 & ILtDM 28 & ++ & Ellipsoid & + & 23.2 & 13.6 \\
\hline 29 & ILtDM 29 & ++ & Ellipsoid & + & 20.2 & 12.6 \\
\hline 30 & ILtDM 30 & +++ & Ellipsoid & +++ & 22.6 & 13.2 \\
\hline
\end{tabular}

* Mean values of three replications; ** Mean values of five replications

- no, + poor, ++ medium, +++ good

Fig.1 Mango dieback disease incidence caused by different isolates of Lasiodiplodia theobromae

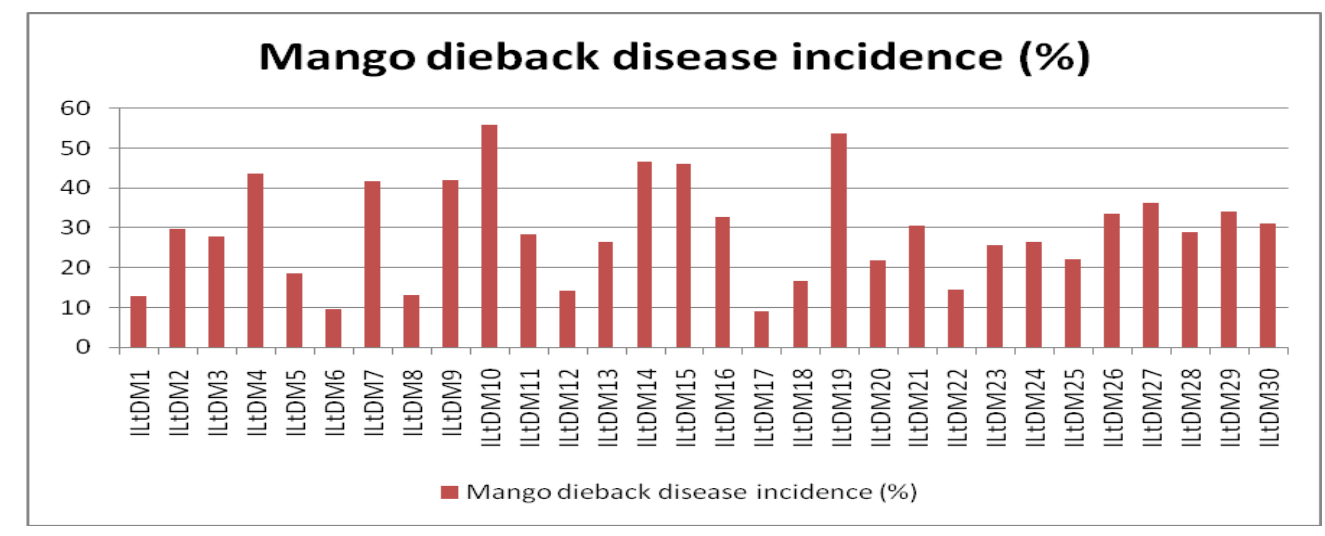


Plate.1 Symptomatology of Mango dieback disease

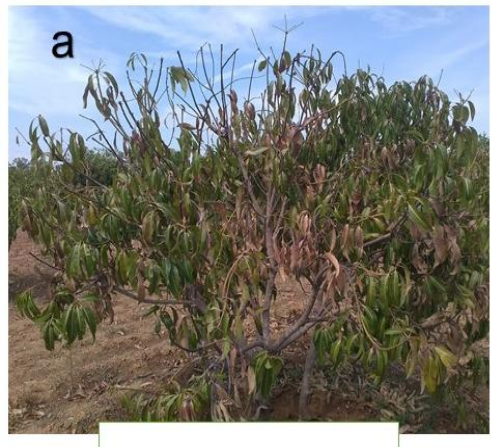

a). Dieback infected tree

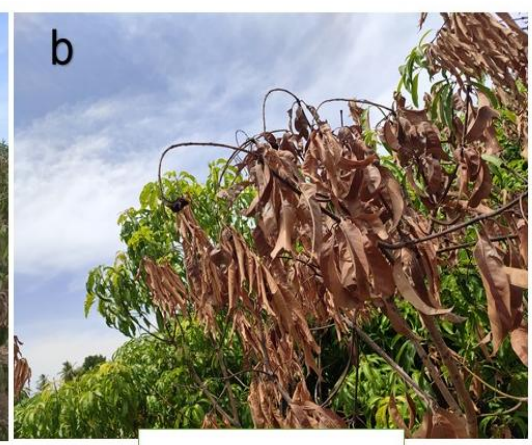

b). Dieback infected branches

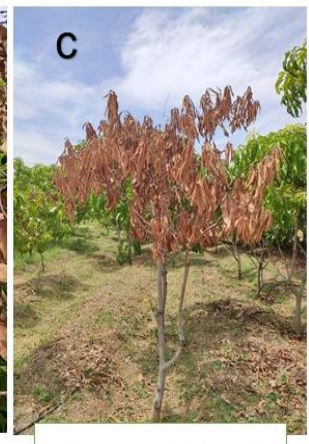

c). Death of dieback infected tree

Plate.2 Variability among mycelial and conidial character
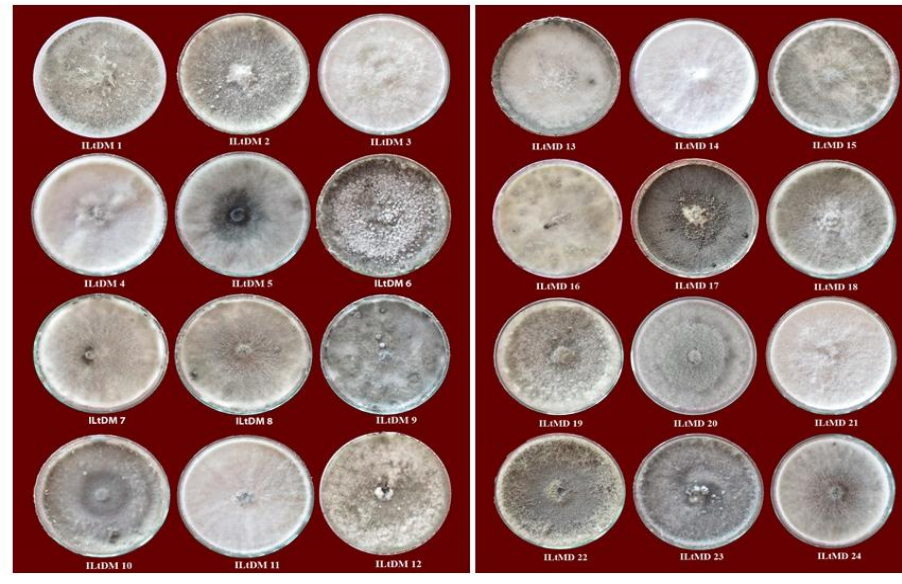

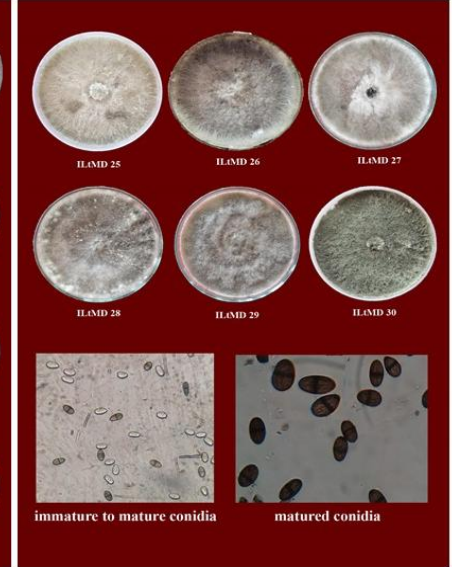

\section{Variability in morphological characters}

\section{Variability in mycelial characters}

Mycelial growth of the pathogen, $L$. theobromae was observed to be hyaline to white coloured initially, which radiated from the small piece of the infected tissue. Upon the maturation of mycelium, it exhibited the colour variation ranging from grey to dark greyish black colour. Pycnidia were observed to be scattered along the periphery of the Petri dish (Table 2).

The colour of matured culture was grey to dark greyish black. Among the isolates greyish white mycelium was produced by the isolates viz., ILtDM1, ILtDM7, ILtDM12, ILtDM19, ILtDM24, ILtDM27, ILtDM28. The isolates viz., ILtDM2, ILtDM8, ILtDM10, ILtDM16 produced grey colour mycelium and ILtDM3, ILtDM4, ILtDM11, ILtDM14, ILtDM21, ILtDM25 produced white coloured mycelium. Blackish grey mycelium was produced by the isolates viz., ILtDM5. ILtDM17, ILtDM30. The isolates ILtDM6, ILtDM9， ILtDM23， ILtDM26, ILtDM29 produced greyish black mycelium and ILtDM15, ILtDM18, ILtDM20, ILtDM22 produced dark grey coloured mycelium (Plate. 2).

Apart from these, isolates of ILtDM5, ILtDM6, ILtDM9, ILtDM17， ILtDM23, 
ILtDM26, ILtDM30 produced dark black pigmentation, ILtDM3, ILtDM4, ILtDM11, ILtDM14, ILtDM21 and ILtDM25 produced dark green to black pigmentation and all others produced black coloured pigmentation.

The pathogenic isolates exhibited three different topographic features viz., aerial, flat and fluffy growth. The isolate ILtDM17 only had flat growth, ILtDM3, ILtDM20 had fluffy growth and remaining all had aerial growth. Margin of different isolates were characterized as smooth and irregular. All isolates produced irregular margin except ILtDM3， ILtDM17， ILtDM20 which produced smooth margin. But the isolate, ILtDM29 alone produced concentric zonation, which was not observed in other isolates.

The isolates ILtDM4, ILtDM9, ILtDM11, ILtDM12， ILtDM16， ILtDM23， ILtDM26, ILtDM28 and ILtDM30 were grown fast and took two days to cover the $9 \mathrm{~cm}$ diameter Petri dish followed by ILtDM1, ILtDM2, ILtDM5， ILtDM6， ILtDM7， ILtDM8， ILtDM10， ILtDM13， ILtDM15，ILtDM17， ILtDM18， ILtDM19， ILtDM20， ILtDM21， ILtDM22，ILtDM24，ILtDM25，ILtDM27, and ILtDM29. These isolates required three days to cover the Petri dish and ILtDM14 required four days. Among all these, the isolate ILtDM3 was very slow and took five days to cover the Petri dish. In this study, culture characters of all the isolates were agreed with the findings of the authors (Goos et al., 1961; Punithalingam, 1976; Ko et al., 2004; Shah et al., 2010; Sathya et al., 2017; Ekanayake et al., 2019).

\section{Variability in spore characters}

Morphological variations in pycnidium and spores of L. theobromae were studied (Table 3). Pycnidia were black and scattered along the periphery of the Petri Dish. Among 30 the isolates, isolates ILtDM6, ILtDM9, ILtDM13,
ILtDM16 and ILtDM30 had more production of pycnidia and sporulation than other isolates. Conidia were initially hyaline, unicellular, sub ovoid to ellipsoid in shape and mature conidia were dark brown to black colour, bi-celled, thick walled, ellipsoidal shape with longitudinal striations (Plate.2). The size of the spore (length and breadth) was in the range between $18.4-26.8 \times 10.6-14.2$ $\mu \mathrm{m}$. Among the isolates, ILtDM5 had the highest length of the spore and the smallest spore length was recorded in with ILtDM6. Such variation in conidial characters was reported by different workers, which was attributed to the inherent genetic variability (Khanzada et al., 2004; Alves et al., 2008; Shah et al., 2010; Phillips et al., 2013).

\section{References}

Al-Adawi, A.O., M. Deadman, A. Al-Rawahi, A. Khan, and Y. Al-Maqbali. 2003. Diplodia theobromae associated with sudden decline of mango in the Sultanate of Oman. Plant Pathology 52 (3).

Al-Jabri, M., M. Al-Shaili, M. Al-Hashmi, A. Nasehi, I. Al-Mahmooli, and A. AlSadi. 2017. Characterization and evaluation of fungicide resistance among Lasiodiplodia theobromae isolates associated with mango dieback in Oman. Journal of plant pathology 99 (3):753-759.

Al Adawi, A., M. Deadman, A. Al Rawahi, Y. Al Maqbali, A. Al Jahwari, B. Al Saadi, I. Al Amri, and M. Wingfield. 2006. Aetiology and causal agents of mango sudden decline disease in the Sultanate of Oman. European Journal of Plant Pathology 116 (4):247-254.

Alves, A., P.W. Crous, A. Correia, and A. Phillips. 2008. Morphological and molecular data reveal cryptic speciation in Lasiodiplodia theobromae. Fungal diversity 28:1-13. 
de Oliveira Costa, V.S., S.J. Michereff, R.B. Martins, C.A.T. Gava, E.S.G. Mizubuti, and M.P.S. Câmara. 2010. Species of Botryosphaeriaceae associated on mango in Brazil. European Journal of Plant Pathology 127 (4):509-519.

Dhingra, O.D., and J.B. Sinclair. 1985. Basic plant pathology methods: CRC Press, Inc.

Ekanayake, G., K. Abeywickrama, A. Daranagama, and S. Kannangara. 2019. Morphological characterization and molecular identification of stem-end rot associated fungal species isolated from 'Karutha Colomban'mango fruits in Sri Lanka. The Journal of Agricultural Sciences-Sri Lanka 14 (2):120-128.

FAO. 2015.

Goos, R.D., E.A. Cox, and G. Stotzky. 1961. Botryodiplodia theobromae and its association with Musa species. Mycologia 53 (3):262-277.

Hong, S.K., S.Y. Lee, H.W. Choi, Y.K. Lee, J.-H. Joa, and H. Shim. 2012. Occurrence of stem-end rot on mango fruits caused by Lasiodiplodia theobromae in Korea. Plant Pathol. J 28 (455): 10.5423.

Khanzada, M.A., A.M. Lodhi, and S. Shahzad. 2004. Mango dieback and gummosis in Sindh, Pakistan caused by Lasiodiplodia theobromae. Plant Health Progress 5 (1):13.

Ko, W., I. Wang, and P. Ann. 2004. Lasiodiplodia theobromae as a causal agent of kumquat dieback in Taiwan. Plant Disease 88 (12):1383-1383.

Madduleti, M. 1989. Studies on die-back and death of mango trees (Mangifera indica L.). Acharya Ng Ranga Agricultural University, Rajendranagar, Hyderabad.

NHB. 2018 - 2019.

Phillips, A., A. Alves, J. Abdollahzadeh, B. Slippers, M.J. Wingfield, J. Groenewald, and P.W. Crous. 2013. The Botryosphaeriaceae: genera and species known from culture. Studies in mycology 76:51-167.

Ploetz, R.C., D. Benscher, A. Vazquez, A. Colls, J. Nagel, and B. Schaffer. 1996. A reexamination of mango decline in Florida. Plant disease (USA).

Prakash, O., and K. Srivastava. 1987. Mango diseases and their management. A world review: Today \& Tomorrow's Printers and Publishers.

Punithalingam, E. 1976. Botryodiplodia theobromae [Descriptions of Fungi and Bacteria]. IMI Descriptions of Fungi and Bacteria (52).

Punithalingam, E. 1980. Plant diseases attributed to Botryodiplodia theobromae Pat: J. Cramer.

Rodríguez-Gálvez, E., P. Guerrero, C. Barradas, P.W. Crous, and A. Alves. 2017. Phylogeny and pathogenicity of Lasiodiplodia species associated with dieback of mango in Peru. Fungal biology 121 (4):452-465.

Saeed, E.E., A. Sham, A. AbuZarqa, K. A Al Shurafa, T. S Al Naqbi, R. Iratni, K. ElTarabily, and S. F AbuQamar. 2017. Detection and management of mango dieback disease in the United Arab Emirates. International journal of molecular sciences 18 (10):2086.

Sathya, K., S. Parthasarathy, G. Thiribhuvanamala, and K. Prabakar. 2017. Morphological and molecular variability of Lasiodiplodia theobromae causing stem end rot of mango in Tamil Nadu, India. Int. J. Pure Appl. Biosci 5:1024-1031.

Shah, M., K. Verma, K. Singh, and R. Kaur. 2010. Morphological, pathological and molecular variability in Botryodiplodia theobromae (Botryosphaeriaceae) isolates associated with die-back and bark canker of pear trees in Punjab, India. Genetics and Molecular Research 9 (2):1217-1228.

Sharma, I., R. Harender, and J. Kaul. 1994. 
Studies on post-harvest diseases of mango and chemical control of stem end rot and anthracnose. Indian Phytopathology 47 (2):197-200.

Teng, P., and W. James. 2002. Disease and yield loss assessment. Plant Pathologist's Pocketbook 3rd Edition: 35.

Tudzynski, P., and A. Sharon. 2003. Fungal pathogenicity genes. Applied mycology and biotechnology 3:187-212.

Úrbez-Torres, J., G. Leavitt, J. Guerrero, J. Guevara, and W. Gubler. 2008. Identification and pathogenicity of Lasiodiplodia theobromae and Diplodia seriata, the causal agents of bot canker disease of grapevines in Mexico. Plant Disease 92 (4):519-529.

\section{How to cite this article:}

Dheivam, M., K. Manonmani, K. Kalpana, C. Senthilraja, M. Theradimani and Rajangam, J. 2020. Studies on Morphological Variability of the Fungal Pathogen, Lasiodiplodia theobromae causing Dieback in Mango. Int.J.Curr.Microbiol.App.Sci. 9(12): 2446-2454.

doi: https://doi.org/10.20546/ijcmas.2020.912.289 